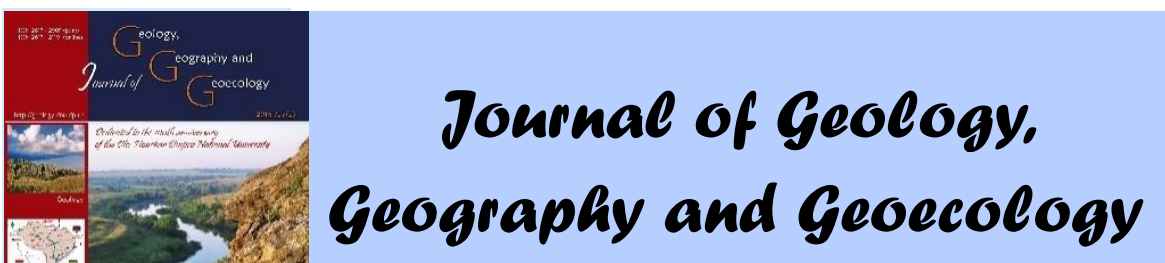

Journal home page: geology-dnu-dp.ua

\title{
The chemical composition of precipitation in Ukraine and its potential impact on the environment and water bodies
}

\author{
V.K. Khilchevskyi ${ }^{1}$, S.M. Kurylo ${ }^{1}$, N.P. Sherstyuk ${ }^{2}$, M.R. Zabokrytska ${ }^{3}$ \\ ${ }^{1}$ Taras Shevchenko National University of Kyiv, Kyiv, Ukraine \\ ${ }^{2}$ Oles Gonchar Dnipro National University, Dnipro, Ukraine, e-mail: sherstuknp@gmail.com \\ ${ }^{3}$ Lesya Ukrainka Eastern European National University, Lutsk, Ukraine
}

Received 15.11.2018;

Received in revised form 20.11.2018;

Accepted 06.02.2019
Abstract. This article provides characteristic of the chemical composition of atmospheric precipitation on the territory of Ukraine and its potential impact on the environment and water bodies. In Ukraine, the rainfall is $650 \mathrm{~mm} / \mathrm{year}$ in the northwest of the country (mixed forests), up to $300 \mathrm{~mm} /$ year in the south (steppe zone), in the Ukrainian Carpathians - up to $1,600 \mathrm{~mm} /$ year. Acidity of atmospheric precipitation $(\mathrm{pH})$ on the territory of Ukraine according to monitoring meteorological stations is 5.9-6.3. Minimum values of mineralization of atmospheric precipitation are observed in a zone of mixed forests in the north of the country. In particular, according to the weather station of Teteriv, the mineralization of atmospheric precipitation is $27.0 \mathrm{mg} / \mathrm{l}$. In forest-steppe and steppe zones, this rate gradually increases to $35-45 \mathrm{mg} / \mathrm{l}$, reaching a maximum in the steppe zone at the Askania-Nova meteorological station $(82.4 \mathrm{mg} / \mathrm{l})$. In the chemical composition of atmospheric precipitation, anion predominates sulfates, and among cations - magnesium. Anthropogenic component of the total mineralization of atmospheric precipitation, calculated for the first time on the territory of Ukraine (meteorological station Kobelyaki) by comparison with the regional natural background, is $69 \%$. Concentration of sulfate ions (8-24 mg/l) in atmospheric precipitation on the territory of Ukraine shows a high level of pollution with sulfur, which corresponds to IV-V levels of environmental pollution. It is noted that with increasing concentrations of sulfates in atmospheric precipitation a tendency towards a decrease in the $\mathrm{pH}$ in the water of Svityaz Lake is projected. Current research shows that at high concentrations of sulfates in atmospheric precipitation, the risk of falling individual rains with low $\mathrm{pH}$ (so-called acid rains) increases. Waters of high concentration of organic matter and low mineralization of water are widely distributed on the territory of Ukraine (catchments of Polissya and the Carpathian region): up to $100 \mathrm{mg} / \mathrm{l}$ in the meadows and up to $30 \mathrm{mg} / \mathrm{l}$ in the flood period. Often, the $\mathrm{pH}$ of water in them is 6-6.5 and precipitation of acidic precipitation can significantly affect their hydroecological state. The obtained results on the influence of chemical composition of atmospheric precipitation on water objects have a diagnostic character. For more specific results, special synchronized studies of the chemical composition of the water of experimental water reservoirs with sampling of atmospheric precipitation are required.

Keywords: atmospheric precipitation, chemical composition, anthropogenic component, environment, water bodies, Ukraine

\section{Хімічний склад атмосферних опадів в Україні та його потенційний вплив на довкілля та водні об'скти}

\author{
В.К. Хільчевськийํㅜ, С.М. Курило ${ }^{1}$, Н.П. Шерстюк², М.Р. Забокрицька ${ }^{3}$
}

${ }^{1}$ Київський національний університет імені Тараса Шевченка, Київ, Украӥна

${ }^{2}$ Дніпровський національний університет імені Олеся Гончара, Дніпро, Україна, е-таil: sherstuknp@gmail.com

${ }^{3}$ Східноєвропейський національний університет імені Лесі Українки, Луцьк, Украӥна 
мінералізації атмосферних опадів, розрахована уперше для території України (метеостанція Кобеляки) методом порівняння 3 регіональним природним фоном, становить $69 \%$. Концентрація іонів сульфатів (8-24 мг/л) в атмосферних опадах на території України свідчить про високий рівень забруднення сіркою, що відповідає IV-V рівням забруднення довкілля. Відзначено, що зі зростанням концентрацій сульфатів в атмосферних опадах намічається тенденція до зменшення $\mathrm{pH}$ у воді озера Світязь. Сучасні дослідження показують, що при високих концентраціях сульфатів в атмосферних опадах зростає ризик випадання окремих дощів з низьким значенням рН (так звані кислотні дощі). На території України (водозбори Полісся і Карпатського регіону) широко поширені водойми з високою концентрацією органічної речовини і низькою мінералізацією води: до 100 мг/л - в межень і до 30 мг/л - в паводковий період. Найчастіше величина рН води в них становить 6-6,5 і випадання кислих атмосферних опадів може істотно вплинути на їхній гідроекологічний стан. Отримані результати по впливу хімічного складу атмосферних опадів на водні об'єкти мають діагностичний характер. Для отримання конкретніших результатів потрібне проведення спеціальних синхронізованих досліджень хімічного складу води експериментальних водойм з відбором проб атмосферних опадів.

Ключеві слова: атмосферні опади, хімічний склад, антропогенна складова, довкілля, водні об'єкти, Украӥна

Introduction. Atmospheric precipitation is involved in the formation of environmental components. In addition to the function of moisture, they add chemical components to the earth's surface. In the last decade, the interest to the study of atmospheric moisture and atmospheric precipitation chemicals has grown significantly across the world (Ham et al., 2010; Nasiruddin Khan and Sarwar, 2014; Vlastos et al., 2018; Wanga and Hanb, 2011; Xiao, 2016). As an integral part of the water and hydrochemical balance of water bodies, atmospheric precipitation can, to a lesser extent, affect their ecological status, especially in conditions of increasing human-induced impacts and climate change (Hodzher, 2005; Khilchevskyi et al., 2018).

In Ukraine, from $650 \mathrm{~mm} / \mathrm{year}$ of precipitation in the northwest of the country (mixed forest zone) falls to $300 \mathrm{~mm} /$ year in the south (steppe zone), in the Ukrainian Carpathians - up to1,600 mm/year.

The purpose of this work: 1) establishment of regional distribution patterns of the chemical composition of atmospheric precipitation in Ukraine; 2) the study of anthropogenic component role in the formation of atmospheric precipitation's chemical composition; 3) diagnostic assessment of the influence of the chemical composition of atmospheric precipitation on water objects as part of the environment.

Material and methods of research. In the article were used archival materials of the Central Geophysical Observatory named after Boris Sreznevsky. This is a monitoring of the chemical composition of atmospheric precipitation in Ukraine on meteorological stations located in different natural zones of Ukraine (Figure 1). All major ions and indicators of total mineralization were determined (anions: $\mathrm{SO}_{4}{ }^{2-}, \mathrm{Cl}^{-}, \mathrm{HCO}_{3}{ }^{-}$and also $\mathrm{NO}_{3}{ }^{-}$; cations: $\mathrm{Ca}^{2+}, \mathrm{Mg}^{2+}, \mathrm{Na}^{+}, \mathrm{K}^{+}$, and $\mathrm{NH}_{4}{ }^{+}$) - see Figure 1. The information on the chemical composition of the total monthly precipitation samples in the territory of Ukraine for the period of 1963-2011 in 10 meteorological stations was processed: Teteriv (Kyiv region), Kiev, Kobelyaky (Poltava region), Bobrynets (Kirovograd region), Loshkarivka (Dnipropetrovsk Oblast), Volnovakha (Donetsk region), Odessa, Askania-Nova (Kherson oblast), Beregove (Transcarpathian region), Nikitsky botanical garden (Autonomous Republic of Crimea). For the characterization, the materials used in the works (Romas and Kosovets, 2007; Kosovets-Skavronska and Snizhko, 2008), the data on single-use atmospheric precipitation samples were taken, which were selected and analyzed during the expeditionary researches of the laboratory of hydrochemistry of the Taras Shevchenko National University of Kyiv (Peleshenko et al., 1986; Khilchevskyi, 2015).

\section{Research results and their discussion}

1. Regional laws of the chemical composition of atmospheric precipitation in Ukraine. The average annual statistically estimated concentrations of main ions in atmospheric precipitation on the territory of Ukraine in the total monthly samples for the period 1963-2011 is shown in Table 1.

Minimum values of mineralization of atmospheric precipitation are observed in the zone of mixed forests in the north of the country. In particular, according to the weather station of Teteriv, the mineralization of atmospheric precipitation is $27.0 \mathrm{mg} / \mathrm{l}$. In the forest-steppe and steppe zones of Ukraine, this rate gradually increases to $35-45 \mathrm{mg} / \mathrm{l}$, reaching a maximum in the steppe zone at the Askania-Nova meteorological station in the Kherson region (82.4 $\mathrm{mg} / \mathrm{l})$. Thus, there is a tendency of increasing mineralization of precipitation from north to south (see Figure 1). Somewhat azonally, the importance of mineralization of atmospheric precipitation, recorded on meteorological stations in mountainous countries (Carpathians and Crimea). 


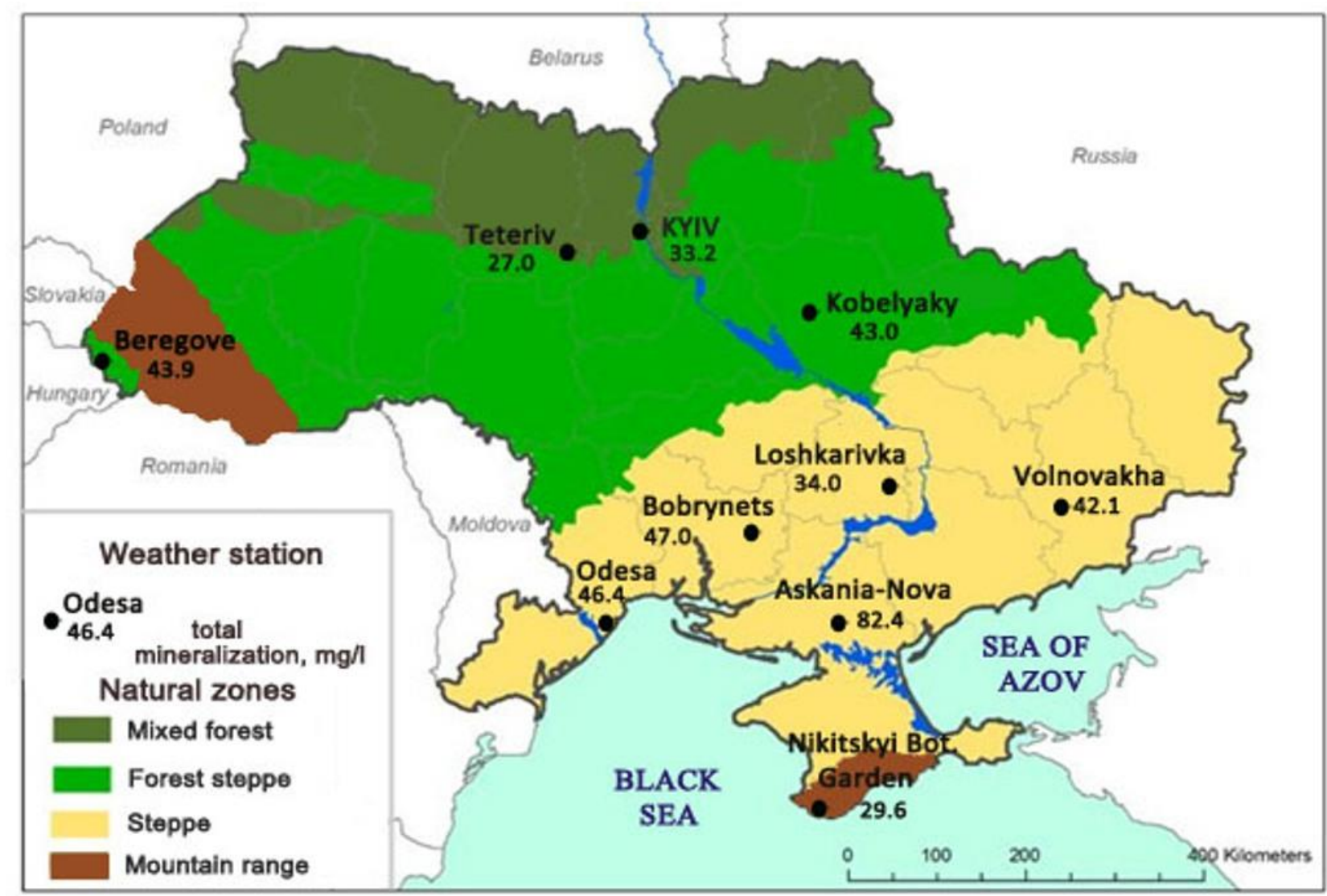

Fig. 1. Meteorological stations on the territory of Ukraine with indicators of total mineralization of atmospheric precipitation, $\mathrm{mg} / \mathrm{l}$

Table 1. Average annual values of $\mathrm{pH}$ (dimensionless), concentrations of basic ions and total mineralization of atmospheric precipitation ( $\mathrm{mg} / \mathrm{l})$ on the territory of Ukraine (in total lunar samples)

\begin{tabular}{|c|c|c|c|c|c|c|c|c|c|c|c|c|}
\hline № & $\begin{array}{l}\text { Meteorological } \\
\text { station }\end{array}$ & $\mathrm{pH}$ & $\mathrm{SO}_{4}^{2-}$ & $\mathrm{Cl}^{-}$ & $\mathrm{HCO}_{3}^{-}$ & $\mathrm{NO}_{3}^{-}$ & $\mathrm{Ca}^{2+}$ & $\mathrm{Mg}^{2+}$ & $\mathrm{Na}^{+}$ & $\mathrm{K}^{+}$ & $\mathrm{NH}_{4}^{+}$ & $\begin{array}{l}\text { Total } \\
\text { minera- } \\
\text { lization }\end{array}$ \\
\hline \multicolumn{13}{|c|}{ Mixed forest zone } \\
\hline 1 & $\begin{array}{l}\text { Teteriv, Kyiv } \\
\text { region }\end{array}$ & 5.9 & 13.7 & 2.0 & 5.0 & 1.9 & 1.8 & 2.0 & 1.5 & 1.0 & 0.9 & 27.0 \\
\hline \multicolumn{13}{|c|}{ Forest-steppe zone } \\
\hline 2 & Kyiv & 6.1 & 15.4 & 1.4 & 11.3 & - & 0.6 & 1.3 & 0.4 & 1.9 & 0.7 & 33.2 \\
\hline 3 & $\begin{array}{l}\text { Kobelyaky, } \\
\text { Poltava region } \\
\end{array}$ & 6.3 & 14.8 & 3.8 & 11.0 & 1.6 & 3.5 & 2.8 & 2.9 & 1.4 & 1.1 & 43.0 \\
\hline \multicolumn{13}{|c|}{ Steppe zone } \\
\hline 4 & $\begin{array}{l}\text { Bobrinets, } \\
\text { Kirovograd } \\
\text { region }\end{array}$ & 6.2 & 15.4 & 3.1 & 14.2 & 1.8 & 4.2 & 4.1 & 2.2 & 1.0 & 1.1 & 47.1 \\
\hline 5 & $\begin{array}{l}\text { Loshkarivka, } \\
\text { Dnipropetrovsk } \\
\text { region }\end{array}$ & 6.1 & 15.0 & 3.3 & 4.9 & 1.7 & 2.7 & 2.2 & 1.7 & 1.0 & 1.6 & 34.0 \\
\hline 6 & $\begin{array}{l}\text { Volnovaha, } \\
\text { Donetsk region }\end{array}$ & 6.6 & 17.8 & 4.3 & 7.6 & 1.7 & 3.0 & 2.8 & 3.2 & 1.4 & 1.3 & 42.1 \\
\hline 7 & Odesa & 6.0 & 18.5 & 7.0 & 7.9 & 2.4 & 3.5 & 2.2 & 3.8 & 1.8 & 1.3 & 46.4 \\
\hline 8 & $\begin{array}{l}\text { Askania-Nova, } \\
\text { Kherson region. }\end{array}$ & 6.4 & 9.6 & 8.5 & 38.0 & - & 1.5 & 13.3 & 2.1 & 9.4 & - & 82.4 \\
\hline \multicolumn{13}{|c|}{ Carpathian mountain country } \\
\hline 9 & $\begin{array}{l}\text { Berehove, } \\
\text { Transcarpathian } \\
\text { region }\end{array}$ & 6.1 & 18.4 & 2.4 & 12.1 & 1.6 & 3.1 & 2.3 & 1.6 & 1.0 & 1.4 & 43.9 \\
\hline \multicolumn{13}{|c|}{ Crimean mountain country } \\
\hline 10 & $\begin{array}{l}\text { Nikitsky } \\
\text { Botanical } \\
\text { Garden, } \\
\text { Autonomous } \\
\text { Republic of } \\
\text { Crimea }\end{array}$ & 6.1 & 9.3 & 3.0 & 8.1 & 1.6 & 2.1 & 1.8 & 1.7 & 1.0 & 1.0 & 29.6 \\
\hline
\end{tabular}


Table 2 shows data on the chemical composition of one-time atmospheric precipitation samples taken during 1975-1987 during conducting expeditionary studies by the laboratory of hydrochemistry of the Taras Shevchenko National University of Kyiv in various natural zones of Ukraine (Khilchevskyi, 2015).

Table 2. The chemical composition of one-time samples of atmospheric precipitation, selected on the territory of Ukraine, $\mathrm{mg} / \mathrm{l}$

\begin{tabular}{|c|c|c|c|c|c|c|c|c|}
\hline Settlement, region & $\mathrm{pH}$ & $\mathrm{SO}_{4}{ }^{2--}$ & $\mathrm{Cl}^{-}$ & $\mathrm{HCO}_{3}^{-}$ & $\mathrm{Ca}^{2+}$ & $\mathrm{Mg}^{2+}$ & $\mathrm{Na}^{+}+\mathrm{K}^{+}$ & $\begin{array}{c}\text { Total } \\
\text { mineralization }\end{array}$ \\
\hline \multicolumn{9}{|c|}{ Mixed forest zone } \\
\hline $\begin{array}{l}\text { Shatsk, } \\
\text { Volyn region }\end{array}$ & 59 & 10.8 & 2.1 & 4.2 & 1.8 & 2.0 & 1.5 & 22.4 \\
\hline $\begin{array}{l}\text { Rudnia-Radovelska, } \\
\text { Zhytomyr region }\end{array}$ & 6.0 & 11.1 & 2.2 & 4.4 & 2.2 & 2.1 & 1.6 & 23.6 \\
\hline \multicolumn{9}{|c|}{ Forest-steppe zone } \\
\hline $\begin{array}{l}\text { Boguslav, } \\
\text { Kyiv region }\end{array}$ & 6.0 & 13.0 & 2.8 & 12.2 & 8.0 & 1.2 & 5.2 & 42.4 \\
\hline \multicolumn{9}{|c|}{ Steppe zone } \\
\hline $\begin{array}{l}\text { Kovalivka, Mykolaiv } \\
\text { region }\end{array}$ & 6.1 & 13.5 & 2.9 & 12.5 & 8.3 & 1.6 & 5.5 & 44.3 \\
\hline
\end{tabular}

One-time samples of atmospheric precipitation were selected in the zone of mixed forests: Shatsk town of Volyn region (Shatskikh lakes district in the basin of the Western Bug River) and village Rudnia-Radovelska Zhytomyr region (Pripyat river basin). In the forest-steppe zone - Boguslav city of Kiev region (Dnipro river basin). In the steppe zone - village Kovalivka of the Mykolaiv region (the basin of the Southern Bug River). Apparently, the chemical composition of atmospheric precipitation of one-time atmospheric precipitation samples is close to the average of long-term data (see Table 1 and Table 2).

2. Anthropogenic component of atmospheric precipitation chemical composition. Anthropogenic component of atmospheric precipitation chemical composition - is the part of the salts that are formed in atmospheric moisture at the expense of human economic activity (mainly the emissions of industry to the atmosphere). It was calculated by comparing the actual data on the chemical composition of atmospheric precipitation with the data of the regional natural background (RNB).

The determination of the regional natural background for the chemical composition of atmospheric precipitation on a planetary scale is performed based on data obtained at the weather stations included in the Global Weather Service of the World Meteorological Organization (WMO/GAW Strategic Plan: 2008-2015).

According to the data of (Svistov et al., 2009), the range of mineralization of atmospheric precipitation in ten meteorological stations monitoring the regional natural background on the territory of the Russian Federation and included in the WMO/WGAO GHA is $3-15 \mathrm{mg} / \mathrm{l}$ (at least 3 $20 \mathrm{mg} / \mathrm{l})$. The lower limit of mineralization of atmospheric precipitation of the RPF is the value of the mineralization of a certain theoretical global natural background (GNB) of atmospheric precipitation approaching the mineralization of distilled water. The upper limit of mineralization of atmospheric precipitation of the RPF is due to the peculiarities of the physical and geographical position of a particular territory. The mineralization of single, weekly or monthly samples of precipitation, which constantly exceeds the level of $15.0 \mathrm{mg} / \mathrm{l}$, means that the air is so polluted by foreign impurities that precipitation does not cope with its purification function. Comparing the obtained background values with the actual data on mineralization of atmospheric precipitation of specific meteorological stations, an anthropogenic component of their chemical composition can be obtained (Khilchevskyi and Kurylo, 2016). The calculation algorithm looks like this:

$$
\mathrm{M}_{\mathrm{antr}}=\mathrm{M}_{\mathrm{act}}-\mathrm{M}_{\mathrm{RNB}},
$$

where $\mathrm{M}_{\text {antr }}$ - anthropogenic component of general mineralization (or concentration of a certain ion) in atmospheric precipitation, $\mathrm{mg} / \mathrm{l}$; $\mathrm{M}_{\mathrm{act}}$ - the actual value of mineralization (or concentration of a certain ion) in atmospheric precipitation, $\mathrm{mg} / \mathrm{l} ; \mathrm{M}_{\mathrm{RNB}}$ - the value of mineralization (or concentration of a certain ion) in atmospheric precipitation, corresponding to the regional natural background (RNB), mg/l. 
Unfortunately, there are no weather stations in Ukraine that would be included in the WMO/GAW program and monitored to determine the regional background for the chemical composition of atmospheric precipitation. Therefore, it was the task of choosing the nearest meteorological station included in the WMO/GAW outside Ukraine to use the data of the RPF. The meteorological station of the Voronezh Biosphere Reserve (Russian Federation) was selected. Data on the quantitative characteristics of the chemical composition of atmospheric precipitation at the meteorological station of the Voronezh Biosphere Reserve for 2008, which are in work (Svistov et al., 2009), were used by us in calculations as a regional natural background (RNB). In Ukraine, as the closest to the distance and the complex of physical and geographical conditions, a meteorological station Kobelyaki $\left(\mathrm{M}_{\mathrm{act}}\right)$ was selected, for which the anthropogenic component of the chemical composition of atmospheric precipitation ( $\mathrm{M}_{\mathrm{antr}}$, $\mathrm{mg} / \mathrm{l}$ and $\mathbf{M}_{\text {antr }}, \%$ ) was calculated in Table 3.

Table 3. Estimation of the anthropogenic component ( $\mathrm{M}_{\mathrm{antr}}, \mathrm{mg} / \mathrm{l}$ and $\left.\mathrm{M}_{\mathrm{antr}}, \%\right)$ of the chemical composition of precipitation for the Kobelyaki metropolitan area (Poltava region) using actual data $\left(\mathrm{M}_{\mathrm{act}}\right)$ and regional natural background data $\left(\mathrm{M}_{\mathrm{RNB}}\right)$

\begin{tabular}{|l|c|c|c|c|c|c|c|c|c|c|}
\hline \multirow{2}{*}{ Indicator } & \multicolumn{4}{|c|}{ Anions } & \multicolumn{5}{c|}{ Cations } & $\begin{array}{l}\text { Total } \\
\text { mineralization }\end{array}$ \\
\cline { 2 - 13 } & $\mathrm{SO}_{4}^{2-}$ & $\mathrm{Cl}^{-}$ & $\mathrm{HCO}_{3}^{-}$ & $\mathrm{NO}_{3}^{-}$ & $\mathrm{Ca}^{2+}$ & $\mathrm{Mg}^{2+}$ & $\mathrm{Na}^{+}$ & $\mathrm{K}^{+}$ & $\mathrm{NH}_{4}^{+}$ & 10.9 \\
\hline $\mathrm{M}_{\mathrm{RNB}}, \mathrm{mg} / \mathrm{l}$ & 3.02 & 1.16 & 1.89 & 1.28 & 1.07 & 0.16 & 1.14 & 0.51 & 0.64 & 35.2 \\
\hline $\mathrm{M}_{\text {act }} \mathrm{mg} / \mathrm{l}$ & 12.7 & 2.13 & 7.53 & 1.9 & 3.67 & 2.11 & 2.73 & 1.21 & 1.18 & 24.3 \\
\hline $\mathrm{M}_{\text {antr }} \mathrm{mg} / \mathrm{l}$ & 9.68 & 0.97 & 5.64 & 0.62 & 2.6 & 1.95 & 1.59 & 0.7 & 0.54 & \\
\hline $\mathrm{M}_{\text {antr, }} \%$ & 76.2 & 45.5 & 74.9 & 32.6 & 70.8 & 92.4 & 58.2 & 57.9 & 45.8 & 69.0 \\
\hline
\end{tabular}

As can be seen from Table 3, the high anthropogenic component of dissolved mineral substances in atmospheric precipitation is characteristic for sulfates $(76.2 \%)$ and magnesium (92.4\%). The concentration of sulfate ions $\left(\mathrm{SO}_{4}{ }^{2-}\right)$ is very much dependent on the amount of sulfur dioxide $\left(\mathrm{SO}_{3}\right)$ released into the atmosphere with industrial gases. A large proportion of magnesium ion $\left(\mathrm{Mg}^{2+}\right)$, which is raised from dust from the earth's surface, is most likely due to the high degree of plowing of the territory of Ukraine. The obtained results correspond with the estimation of the chemical composition of atmospheric precipitation in the territory of the middle zone of the European territory of Russia (Svistov et al., 2012).

\section{Diagnostic assessment of the ecological state of the environment based on data on the chemical composition of atmospheric precipitation.}

Atmospheric precipitation not only moisturizes the earth's surface, but also chemically affects the components of the environment. So, it has been shown earlier that the ion flow of rivers on the territory of Ukraine is formed at the expense of salts brought with atmospheric precipitation as follows: $20 \%$ - in the steppe zone; $31 \%$ - in the forest-steppe zone; by $38 \%$ - in the zone of mixed forests. In the Carpathians and the Crimean Mountains, this value reaches $80-85 \%$ (Horiev et al., 1995).

According to the results of observations on the chemical composition of atmospheric precipitation, an indirect diagnostic assessment of the environmental state of the environment can be carried out. Table 4 presents data on environmental assessment criteria from different sources (Svistov, et al., 2010).

Table 4. Estimation of the level of environmental pollution by data on the chemical composition of atmospheric precipitation

\begin{tabular}{|c|c|c|c|c|c|c|}
\hline \multirow{2}{*}{$\begin{array}{l}\text { Chemical } \\
\begin{array}{l}\text { indicator } \\
\text { in atmospheric conditions } \\
\text { precipitation }\end{array}\end{array}$} & \multicolumn{6}{|c|}{ The level of environmental pollution $(0-\mathrm{V})$} \\
\hline & 0 & I & II & III & IV & V \\
\hline \multirow{2}{*}{$\mathrm{pH}$} & $5.5-6.5$ & $5.0-5.5$ & $4.5-5.0$ & $4.0-4.5$ & $3.5-4.0$ & $<3.5$ \\
\hline & & $6.5-7.0$ & $7.0-7.5$ & $7.5-8.0$ & $8.0-8.5$ & $>8.5$ \\
\hline Total mineralization, $\mathrm{mg} / \mathrm{l}$ & $<3$ & $3-15$ & $15-30$ & $30-50$ & $50-100$ & $>100$ \\
\hline $\mathrm{SO}_{4}{ }^{2-}, \mathrm{mg} / \mathrm{l}$ & $<1.0$ & $1-3$ & $3-5$ & $5-7$ & $7-10$ & $>10$ \\
\hline $\mathrm{NO}_{3}^{-}, \mathrm{mg} / \mathrm{l}$ & $<0.1$ & $0.1-1$ & $1-2$ & $2-4$ & $4-7$ & $>7$ \\
\hline $\mathrm{NH}_{4}{ }^{+}, \mathrm{mg} / \mathrm{l}$ & $<0.1$ & $0.1-0.5$ & $0.5-1$ & $1-2$ & $2-5$ & $>5$ \\
\hline $\begin{array}{l}\text { Assessment of changes in ecosystem } \\
\text { status }\end{array}$ & none & weak & strong & oppression & oppression & destruction \\
\hline $\begin{array}{l}\text { Ecological } \\
\text { zone }\end{array}$ & \multicolumn{2}{|c|}{ ecological norm } & risk area & crisis zone & \multicolumn{2}{|c|}{ ecological disaster zone } \\
\hline
\end{tabular}


The greatest danger to ecosystems is the acidity of atmospheric precipitation ( $\mathrm{pH}$ value). The acidity of atmospheric precipitation is determined and regulated by the concentration of $\mathrm{CO}_{2}$ in the air. In the absence of other factors, the $\mathrm{pH}$ of atmospheric precipitation is close to 5.6. However, significant concentrations of sulfate ions $\left(\mathrm{SO}_{4}{ }^{2-}\right)$ in low-mineralized waters can significantly reduce the $\mathrm{pH}$ of the aqueous medium. As recent studies have shown, the growth of acidity of atmospheric precipitation was observed mainly in rains, characterized by a low overall concentration of ions, predominance of sulfate ions and low buffer capacity (Hodzher, 2005).

That is, at high concentrations of $\mathrm{SO}_{4}{ }^{2-}$ there is a high risk of loss of individual atmospheric precipitation with low $\mathrm{pH}$ (acid rain). This can lead to negative consequences for the environment as a whole and for individual water bodies in particular. First of all, it concerns small lakes and ponds with a high proportion of atmospheric nutrition in the water balance. In this case, the constant lack of cations of alkali and alkaline earth metals in the composition of atmospheric water and incomplete neutralization of acidity create a real possibility of acidification of surface water.

For the territory of Ukraine, such processes may be characteristic of the catchment areas of the Ukrainian Polissya and the Carpathian region. In these territories, reservoirs with a high concentration of organic matter and low mineralization of water are distributed: up to 100 $\mathrm{mg} / \mathrm{l}$ in the meadows and up to $30 \mathrm{mg} / \mathrm{l}$ in the flood period (Horiev et al., 1995; Khilchevsky et al., 2012). Most often, the $\mathrm{pH}$ of water in these reservoirs is 6-6.5 and the precipitation of acid rain can significantly affect their hydroecological state. It should also be noted that sulfate $\left(\mathrm{SO}_{4}{ }^{2-}\right)$ and nitrate $\left(\mathrm{NO}_{3}^{-}\right)$ions in atmospheric precipitation are products of oxidation of sulfur and nitrogen oxides from the air. In general, the scheme of these processes can be represented as follows.

For sulfate ions:

$\mathrm{SO}_{2} \rightarrow \mathrm{SO}_{3}{ }^{2-} \rightarrow \mathrm{SO}_{4}{ }^{2-}$.

For nitrate ions:

$\mathrm{NO}_{2} \rightarrow \mathrm{NO}_{2}{ }^{-} \rightarrow \mathrm{NO}_{3}{ }^{-}$.

Moreover, intermediate sulfites $\left(\mathrm{SO}_{3}{ }^{2-}\right)$ and nitrites $\left(\mathrm{NO}_{2}{ }^{-}\right)$in the solution approximately 50 times are more toxic than sulfates $\left(\mathrm{SO}_{4}{ }^{2-}\right)$ and nitrates $\left(\mathrm{NO}_{3}^{-}\right)$.

Total mineralization characterizes the total pollution of atmospheric precipitation, but its direct influence on the toxicity of atmospheric precipitation is small. The indicator of general mineralization is convenient for estimating the possible concentration of atmospheric precipitation of individual components of the chemical composition. The concentration of ions $\mathrm{SO}_{4}{ }^{2-}$ in atmospheric precipitation in the territory of Ukraine $(9.6-18.5 \mathrm{mg} / \mathrm{l})$ indicates a high level of pollution of the atmosphere with sulfur (see Table 1), which corresponds to the level of environmental pollution IV-V (see Table 4). Under such concentrations, $\mathrm{SO}_{4}{ }^{2-}$ assessment of changes in the state of ecosystems shows "possible death", and the ecological zone has a level - "zone of ecological disaster".

It should be noted that the danger is not the absolute concentration of $\mathrm{SO}_{4}{ }^{2-}$, but its potential impact on the $\mathrm{pH}$ of the aqueous medium (change of $\mathrm{pH}$ in the sour side). An example of such an effect on the pH of the lake Svityaz Lake (Shatsky lakes, basin of the West Bug) is shown in Figure 2. As shown in Figure 2, with the increasing concentration of $\mathrm{SO}_{4}{ }^{2-}$ in atmospheric precipitation, the trend is to decrease the $\mathrm{pH}$ in the water of Svityaz Lake.

Somewhat better situation with concentrations of $\mathrm{NO}_{3}^{-}(1.6-2.4 \mathrm{mg} / \mathrm{l})$, they correspond to level II of pollution (ecological "risk zone", in the ecosystems are possible "strong changes"). The concentration of $\mathrm{NH}_{4}{ }^{+}$(1.0-1.55 $\mathrm{mg} / \mathrm{l})$ in atmospheric precipitation corresponds to the third level of pollution - the ecological "crisis zone", the possible oppression of ecosystems (Table 5). As already noted, general mineralization characterizes the total pollution of atmospheric precipitation. According to this indicator, the territory of Ukraine in most cases corresponds to the third level of pollution - the ecological "zone of crisis", the possible oppression of ecosystems.

The obtained values of the level of environmental pollution are well correlated with the magnitude of anthropogenic component in atmospheric precipitation. Thus, the formation of the concentration of sulfate ion $\left(\mathrm{SO}_{4}{ }^{2-}\right)$ has an influence on the anthropogenic component - more than $76 \%$. For this indicator, the maximum levels of environmental pollution and the possible negative impact on the ecosystem are V - level of pollution practically for the whole territory of Ukraine. The share of anthropogenic component in the formation of concentrations of nitrate $\left(\mathrm{NO}^{3-}\right)$ and ammonium $\left(\mathrm{NH}_{4}{ }^{+}\right)$ions is the smallest $32.6 \%$ and $45.8 \%$ respectively. The level of environmental pollution on these indicators is also the smallest (II-III). In this example (Table 5), the $\mathrm{pH}$ of atmospheric precipitation is not considered. Because averaged data on the amount of $\mathrm{pH}$ available in the monitoring network does not give an idea of the real acidity of individual rains, as a consequence of the rapid change in $\mathrm{pH}$ in time. 


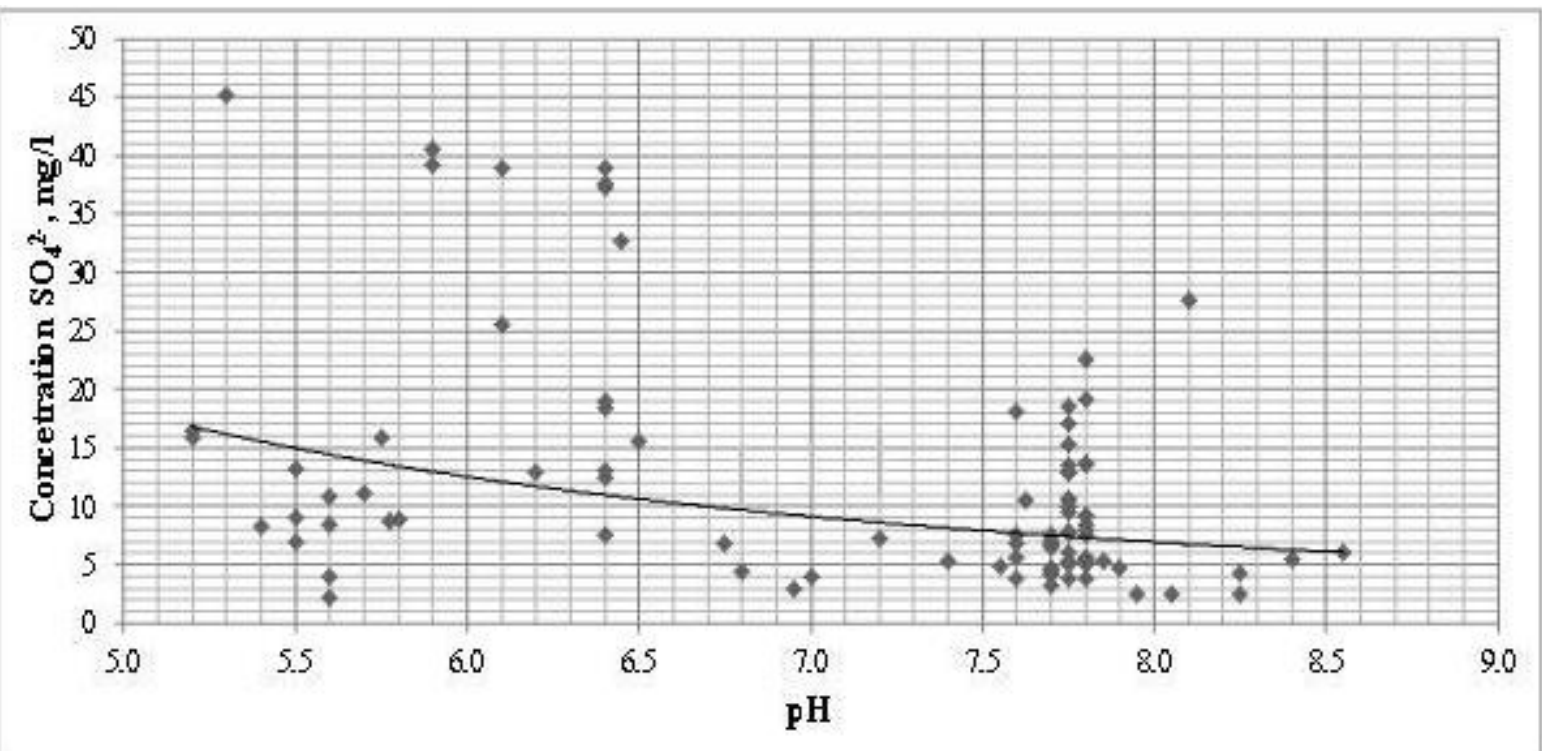

Fig. 2. The dependence of the $\mathrm{pH}$ of the lake Svityaz Lake (Shatsky lakes, the basin of the Western Bug River) on the concentration of sulfate ions $\left(\mathrm{SO}_{4}^{2-}\right)$ in atmospheric precipitation for the average monthly values, 1990-2015

Table 5. Estimation of the level of environmental pollution in Ukraine on the chemical composition of atmospheric precipitation

\begin{tabular}{|l|c|c|c|c|}
\hline \multirow{2}{*}{ Meteorological station } & \multicolumn{4}{|c|}{ The level of environmental pollution $(0-\mathrm{V})$} \\
\cline { 2 - 5 } & $\mathrm{SO}_{4}{ }^{2-}$ & $\mathrm{NO}_{3}^{-}$ & $\mathrm{NH}_{4}{ }^{+}$ & Total mineralization \\
\hline Teteriv & $\mathrm{V}$ & $\mathrm{II}$ & II & II \\
\hline Kyiv & $\mathrm{V}$ & $\mathrm{II}$ & II & III \\
\hline Kobelyaky & $\mathrm{V}$ & II & III & III \\
\hline Bobrinets & V & II & III & III \\
\hline Loshkarivka & V & II & III & III \\
\hline Volnovaha & V & II & III & III \\
\hline Odessa & V & III & III & III \\
\hline Beregove & V & II & II & II \\
\hline Nikitsky Botanical Garden & IV & II & & \\
\hline
\end{tabular}

\section{Conclusions}

1. Acidity of atmospheric precipitation $(\mathrm{pH})$ on the territory of Ukraine according to monitoring meteorological stations is 5.9-6.3.

2. The general mineralization of atmospheric precipitation in the territory of Ukraine usually fluctuates within $30-40 \mathrm{mg} / \mathrm{l}$. There is a tendency to increase this indicator from north to south - from the zone of mixed forests to the steppe zone.

3. In the chemical composition of atmospheric precipitation among the anions dominated by sulfates, and among cations magnesium.

4. The calculated anthropogenic component of the total mineralization of atmospheric precipitation for the territory of Ukraine is 69\% (meteorological station Kobelyaki).

5. The concentration of ions $\mathrm{SO}_{4}{ }^{2-}(8-24$ $\mathrm{mg} / \mathrm{l})$ in atmospheric precipitation on the territory of Ukraine indicates a high level of pollution with sulfur, which corresponds to IV-V levels of pollution ("ecological disaster zone"). Modern studies show that at high concentrations of $\mathrm{SO}_{4}{ }^{2-}$ in atmospheric precipitation, the risk of falling individual rains with low $\mathrm{pH}$ (so-called acid rains) increases. This can lead to negative consequences for the environment as a whole and for individual water bodies in particular. Waters of high concentration of organic matter and low mineralization of water are widely distributed on the territory of Ukraine (catchments of Polissya and the Carpathian region): up to $100 \mathrm{mg} / \mathrm{l}$ in the meadows and up to $30 \mathrm{mg} / \mathrm{l}$ in the flood period.

6 . With the growth of sulfate concentrations in atmospheric precipitation, there is a tendency to decrease the $\mathrm{pH}$ in the water of Lake Svityaz.

7. The results obtained on the influence of the chemical composition of atmospheric precipitation on water objects are diagnostic in nature. For more specific results, special synchronized studies of the chemical composition 
of the water of experimental water reservoirs with sampling of atmospheric precipitation are required.

\section{References}

Ham Y.-S., Kobori H., Kang J.-H., Kim J.H., 2010. Ammonium Nitrogen Deposition as a Dominant Source of Nitrogen in a Forested Watershed Experiencing Acid Rain in Central Japan. Water, Air, \& Soil Pollution. 212 (1-4). 337-344. Retrieved from https://link.springer.com/article/10.1007/s11270010-0347-7.

Hodzher T.V., 2005. Issledovanie sostava atmosfernyh vypadenij $\mathrm{i}$ ih vozdejstviya na ekosistemy Bajkalskoj prirodnoj territorii [Investigation of the composition of atmospheric deposition and their impact on the ecosystems of the Baikal natural territory]. Avtoref. dis. ... kand. geogr. nauk. Moskva. 44 s. (in Russia).

Horiev L.M., Peleshenko V.I., Khilchevskyi V.K., 1995. Hidrokhimiia Ukrainy [Hydrochemistry of Ukraine]. Vyshcha shkola, Kyiv (in Ukrainian).

Khilchevskyi V.K., 2015. Pershi kompleksni gidrohimichni doslidzhennya Shackih ozer na Volyni u 1975 r. - pochatok formuvannya naukovoyi shkoli gidrohimiyi ta gidroekologiyi Kiyivskogo nacionalnogo universitetu imeni Tarasa Shevchenko [The first hydrochemical researches of Shatski lakes in the Volyn region in 1975 - the beginning of the formation hydrochemistry and hydroecology scientific school of the Taras Shevchenko National University of Kyiv]. Hidrolohiia, hidrokhimiia i hidroekolohiia. 39 (4). 64-71 (in Ukranian).

Khilchevskyi V.K., Kurylo S.M., 2016. Khimichnyi sklad atmosfernykh opadiv na terytorii Ukrainy ta yoho antropohenna skladova [Chemical composition of precipitation in Ukraine and its anthropogenic component]. Hidrolohiia, hidrokhimiia i hidroekolohiia. 43(4). 63-74 (in Ukranian).

Khilchevskyi V.K., Kurylo S.M., Sherstyuk N.P., 2018. Chemical composition of different types of natural waters in Ukraine. Journal of Geology, Geography and Geoecology. 27(1), 68-80. Retrieved from https://doi.org/10.15421/111832.

Khilchevskyi V.K., Osadchyi V.I., Kurylo S.M., 2012. Osnovy gidrohimii [Basics of hydrochemistry]. Nika-Tsentr, Kyiv (in Ukranian).

Kosovets-Skavronska O.O., Snizhko S.I., 2008. Chasova transformatsiia khimichnoho skladu atmosfernykh opadiv na terytorii Ukrainy [Temporal transformation of the chemical composition of atmospheric precipitation in the territory of Ukraine]. Ekonomichna ta sotsialna heohrafiia. 58. 242-252 (in Ukranian).

Nasiruddin Khan M., Sarwar A., 2014. Chemical composition of wet precipitation of air pollutants: A case study in Karachi, Pakistan. Atmosfera. 27 (1). 35-46.
Peleshenko V.I., Romas N.I., Khilchevskyi V.K., 1986. Vliyanie antropogennyh faktorov na himicheskij sostav snezhnogo pokrova g. Kieva i prilegayushih rajonov [The influence of anthropogenic factors on the chemical composition of the snow cover in the city of Kyiv and adjacent areas]. Gidrohimicheskie materialy. 13 (DSP). 3-9 (in Russia).

Romas M.I., Kosovets O.O., 2007. Formuvannia khimichnoho skladu atmosfernykh opadiv na terytorii Ukrainy [Formulation of the chemical composition of atmospheric precipitation in the territory of Ukraine]. Hidrolohiia, hidrokhimiia i hidroekolohiia. 12. 172-181 (in Ukranian).

Svistov P.F., Polishuk A.I., Pershina N.A., 2009. Fonovyj uroven sostoyaniya atmosfery po mnogoletnim dannym o himicheskom sostave atmosfernyh osadkov [The background level of the state of the atmosphere from long-term data on the chemical composition of atmospheric precipitation]. Trudy GGO im. A.I. Voejkova. (560), 116-143 (in Russia).

Svistov P.F., Polishuk A.I., Pershina N.A., 2010. Kachestvennaya ocenka zagryazneniya okruzhayushej sredy (po dannym o himicheskom sostave atmosfernyh osadkov) [A qualitative assessment of environmental pollution (according to the chemical composition of atmospheric precipitation)]. Trudy GGO im. A.I. Voejkova. Spec. vypusk 2. 4-17 (in Russia).

Svistov P.F., Polishuk A.I., Pershina N.A., 2012. Mineralizaciya osadkov $\mathrm{v}$ diagnoze izmenenij zagryazneniya okruzhayushej prirodnoj sredy [Mineralization of precipitation in the diagnosis of changes in environmental pollution]. Tezisy dokl. mezhdunar. nauchn. konferencii po regionalnym problemam gidrometeorologii i monitoringa okruzh. sredy. 305-307. Kazan (in Russia).

Vlastos D. et all., 2018. Assessment of the toxic potential of rainwater precipitation: First evidence from a case study in three Greek cities. Science of The Total Environment. 648. 13231332. Retrieved from https://doi.org/10.1016/j.scitotenv.2018.08.166.

Wanga H., Hanb G., 2011. Chemical composition of rainwater and anthropogenic influences in Chengdu, Southwest China. Atmospheric Research. 99(2). 190-196. Retrieved from https://doi.org/10.1016/j.atmosres.2010.10.004.

WMO/GAW Strategic Plan: 2008 - 2015. A contribution to the implementation of the WMO Strategic Plan 2008 - 2011. WMO, GAW, No. 172. TD No. 1384. Retrieved from http://www.wmo-gawwcc-aerosol-physics.org/files/gaw-172.pdf.

Xiao Jun, 2016. Chemical composition and source identification of rainwater constituents at an urban site in Xi'an. Environmental Earth Sciences. 75(3). Retrieved from https://link.springer.com/article/10.1007/s12665015-4997-z. 